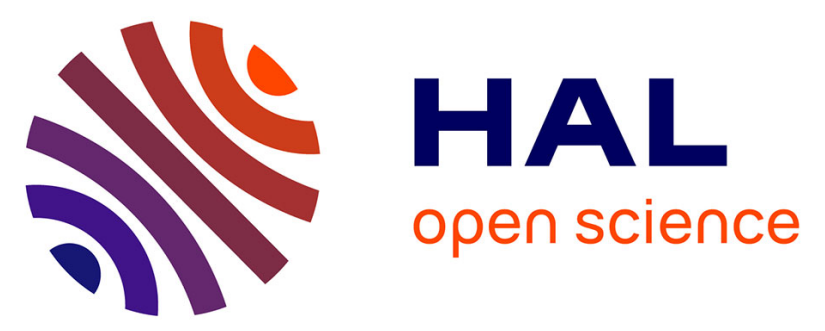

\title{
JC VIRUS DNA IN THE PERIPHERAL BLOOD OF RENAL TRANSPLANT PATIENTS: A ONE-YEAR PROSPECTIVE FOLLOW-UP IN FRANCE
}

Catherine Mengelle, Nassim Kamar, Jean Michel Mansuy, Karine Sandres-Sauné, Florence Legrand-Abravanel, Marcel Miédougé, Lionel Rostaing, Jacques Izopet

\section{To cite this version:}

Catherine Mengelle, Nassim Kamar, Jean Michel Mansuy, Karine Sandres-Sauné, Florence LegrandAbravanel, et al.. JC VIRUS DNA IN THE PERIPHERAL BLOOD OF RENAL TRANSPLANT PATIENTS: A ONE-YEAR PROSPECTIVE FOLLOW-UP IN FRANCE. Journal of Medical Virology, 2010, 83 (1), pp.132. 10.1002/jmv.21951 . hal-00599775

\section{HAL Id: hal-00599775 https://hal.science/hal-00599775}

Submitted on 11 Jun 2011

HAL is a multi-disciplinary open access archive for the deposit and dissemination of scientific research documents, whether they are published or not. The documents may come from teaching and research institutions in France or abroad, or from public or private research centers.
L'archive ouverte pluridisciplinaire HAL, est destinée au dépôt et à la diffusion de documents scientifiques de niveau recherche, publiés ou non, émanant des établissements d'enseignement et de recherche français ou étrangers, des laboratoires publics ou privés. 


\section{JC VIRUS DNA IN THE PERIPHERAL BLOOD OF RENAL TRANSPLANT PATIENTS: A ONE-YEAR PROSPECTIVE FOLLOW-UP IN FRANCE}

\begin{tabular}{|r|l|}
\hline Journal: & Journal of Medical Virology \\
\hline Manuscript ID: & JMV-09-1320.R2 \\
\hline Date - Manuscript type: & Research Article \\
\hline Author: & O4-Aug-2010 \\
\hline Complete List of Authors: & $\begin{array}{l}\text { Mengelle, Catherine; University hospital, Virology } \\
\text { KAMAR, Nassim; CHU Rangueil, Nephrology, Dialysis, and Multi- } \\
\text { Organ Transplantation; Inserm U563 } \\
\text { MANSUY, Jean Michel; University hospital, Virology } \\
\text { Sauné, Karine; University hospital, Virology; Inserm U563 } \\
\text { Abravanel, Florence; University hospital, Virology; Inserm U563 } \\
\text { Miédougé, Marcel; University Hospital, Virology } \\
\text { Rostaing, Lionel; CHU Rangueil, Nephrology, Dialysis, and Multi- } \\
\text { Organ Transplantation; Inserm U563 } \\
\text { Izopet, Jacques; University Hospital, Virology; Inserm U563 }\end{array}$ \\
\hline Keywords: & $\begin{array}{l}\text { Polyomavirus, solid-organ transplantation, immunosuppressive } \\
\text { treatment, nephropathy, progressive multifocal leuko- } \\
\text { encephalopathy }\end{array}$ \\
\hline
\end{tabular}

\section{SCHOLARONE ${ }^{m}$ Manuscripts}




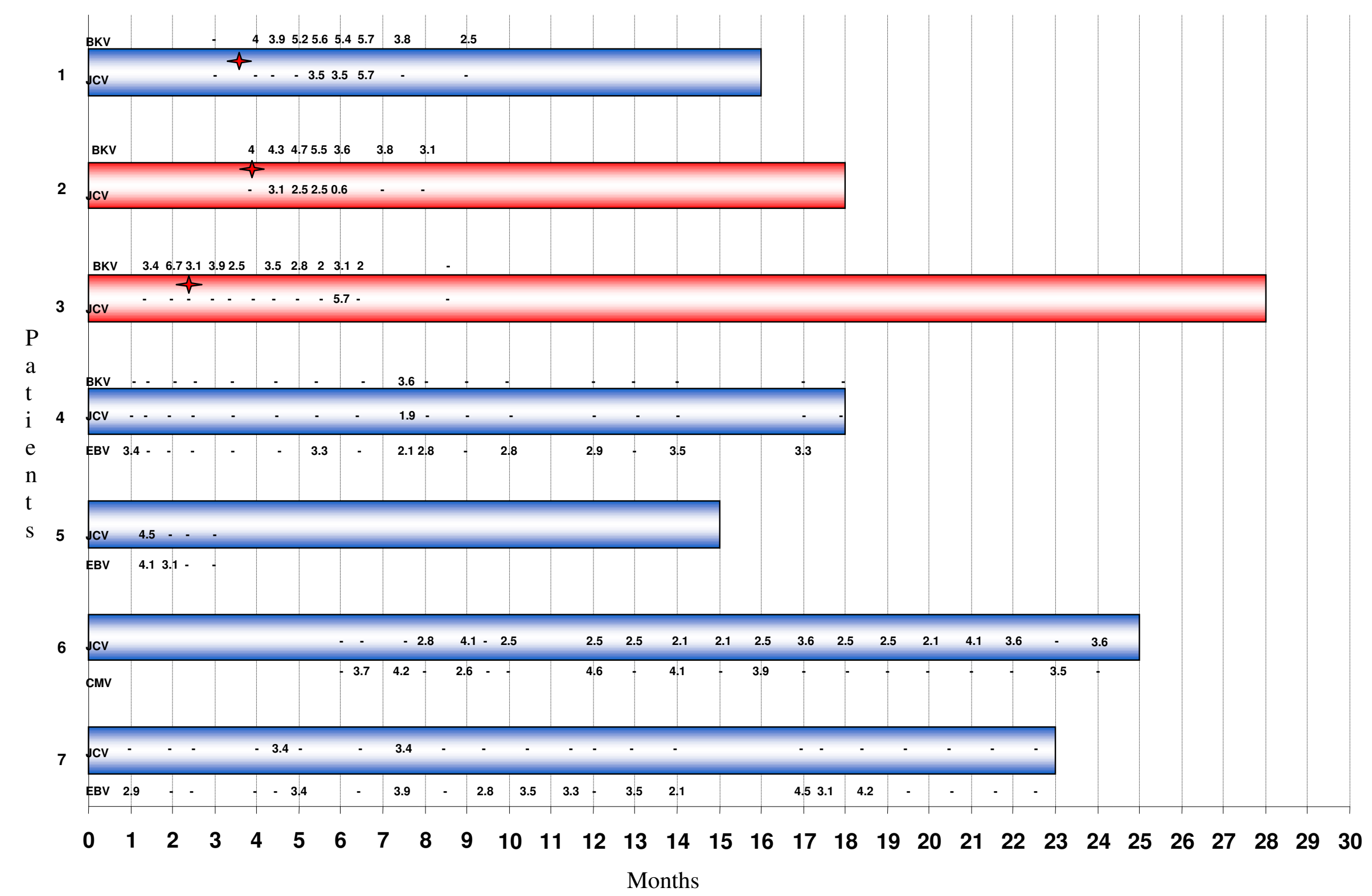


Fig.1: Follow up of patients with JCV-DNA positive in whole blood.

Horizontal bars represent months of follow-up.

Red horizontal bars are those patients treated with rituximab

Virus loads are expressed as $\log _{10}$ copies $/ \mathrm{mL}$.

Red stars represent detection of Decoy cells. 
JC VIRUS DNA IN THE PERIPHERAL BLOOD OF RENAL TRANSPLANT

2 PATIENTS: A ONE-YEAR PROSPECTIVE FOLLOW-UP IN FRANCE

3

4 C Mengelle ${ }^{0, *}, \mathrm{~N}$ Kamar, ${ }^{1,2}, \mathrm{~J}^{-M}$ Mansuy $^{0}, \mathrm{~K}$ Sandres-Sauné ${ }^{0,3}, \mathrm{~F}_{\text {Legrand-Abravanel }}{ }^{0,3}, \mathrm{M}$

$5 \quad$ Miédougé $^{0}$, L Rostaing $^{1,2}$, J Izopet $^{0,3}$

$6{ }^{0}$ Department of Virology, University Hospital, CH Toulouse, 330 Ave. de Grande-Bretagne, TSA

7 40031, 31059 Toulouse Cedex 9, France

$8{ }^{1}$ Nephrology, Dialysis, and Multiorgan Transplant Unit, University Hospital, CH Toulouse, 1 av.

9 J. Poulhes, TSA 50032, 31059 Toulouse Cedex 9, France

$10 \quad{ }^{2}$ : INSERM U858, IFR 31, 1 av. Jean Poulhès, TSA 50032, 31059 Toulouse Cedex 9, France

$11{ }^{3}$ : INSERM U563, IFR 30, 330 Ave. de Grande-Bretagne, TSA 40031, 31059 Toulouse Cedex 9, 12 France.

$14 *$ Correspondance to:

15 Catherine Mengelle

16 Department of Virology

17 Federative institute of Biology

18330 Avenue de Grande Bretagne

19 TSA 40031

2031059 Toulouse Cedex 09

$21 \quad$ France

22 Phone : 33567690419

23 Fax : 33567690425

24 E-mail : mengelle.c@,chu-toulouse.fr

25

26 Shortened title: JCV infection in renal transplantation 


\section{Abstract}

28 There is little information on JC virus (JCV) infection in renal transplant patients. A long-term 29 prospective follow-up study was conducted to assess the incidence of JCV DNA in the blood of 30103 adult renal transplant patients enrolled prospectively between 1 January and 31 December, 31 2006. Patients were monitored until April, 2008. JCV DNA was quantified by a real-time 32 polymerase chain reaction in whole blood samples collected regularly for at least one year post33 transplant.

34 JCV was detected in seven patients $(6.8 \%)(31 / 1487$ whole blood samples) at a median time of 35139 days post-transplant. The median JC virus load of the first positive DNA blood sample was $363.4 \log _{10}$ copies/mL $\left(1.9-5.7 \log _{10}\right.$ copies $\left./ \mathrm{mL}\right)$. Induction therapy were either anti-CD25 37 monoclonal antibodies $(n=5)$ or antithymocyte globulins $(n=2)$. Post-transplant 38 immunosuppressive treatment included steroids with tacrolimus/mycophenolate mofetil (MMF) $39(n=2)$, or ciclosporin/MMF $(n=1)$, or belatacept/MMF $(n=4)$. Two patients were also treated 40 with rituximab. All seven patients infected with JCV had other viral infections(s): BK virus (3), 41 Epstein-Barr virus (2), Cytomegalovirus (1) or both BK virus and Epstein-Barr virus (1). Three 42 patients had BKV-associated nephropathy and decoy cells shedding. JCV infection was not 43 associated with acute rejection episodes or nephropathy, regardless of the virus load. No patient 44 developed progressive multifocal leukoencephalopathy during follow-up.

45 Thus the incidence of JCV infection in renal transplant patients was low and not associated with 46 any specific clinical manifestations. JCV replication must still be diagnosed and differentiated 47 from BK virus infection because of its non-aggressive course.

49 Key words: Polyomavirus, nephropathy, progressive multifocal leukoencephalopathy, solid-organ 50 transplantation, immunosuppressive treatment 


\section{Introduction}

52

53

JC virus (JCV) is a member of the Polyomaviridae, which include other human viruses such as BK virus, KI [Allander et al., 2007], WU [Gaynor et al., 2007] and SV40. JC and BK virus infections are frequent and occur early in childhood. Seropositivity increases with age; BKV reaches a seroprevalence of $91 \%$ in children aged 5-9 years, while seroprevalence of JCV reaches only 50\% by the age of 60-69 years [Knowles et al., 2003]. The transmission routes are not yet clear but are thought to be via the respiratory tract, although oral-fecal transmission is also possible.

Both viruses remain latent in the kidney, in B lymphocytes [Lafon et al., 1998; Monaco et al., 1996] and in the central nervous system after primary infection, but they may be reactivated at any time. JCV excretion in the urine can reach $46 \%$ in immunocompetent patients, and the virus usually remains asymptomatic [Pagani et al., 2003; Rossi et al., 2007]. However, reactivation of either virus in immunosuppressed patients can cause several clinical syndromes. JCV can become reactivated in patients infected with HIV, transplant recipients and patients with cancer, and may produce progressive multifocal leukoencephalopathy, a fatal neurological demyelinating disease [Hou and Major, 2000]. Polyomavirus-associated nephropathy in renal transplant patients is mostly due to BKV, but recent studies have shown that JCV infection may also be involved [Drachenberg et al., 2007].

Little is known at present on the incidence of JCV infection and its clinical consequences in these patients.

This prospective long-term follow-up study assessed the incidence of JCV shedding in whole blood samples from renal transplant recipients. The results were correlated with immunosuppressive treatment and the virological parameters of the patients who excreted JC virus. 


\section{Materials and methods}

76 Patients

77 Adult renal transplant recipients under the care of Toulouse University Hospital were enrolled 78 prospectively from 1 January to 31 December, 2006 and were monitored until April, 2008.

79 Any induction therapy was based on antithymocyte globulins or anti-CD25 monoclonal 80 antibodies. All patients were treated with steroids for post-transplant immunosuppression. They 81 were also given tacrolimus/mycophenolate mofetil (MMF), or cyclosporin A/MMF, 82 belatacept/MMF, or cyclosporin/everolimus. Renal biopsies were taken when acute rejection was 83 suspected. The patients were given three injections of methylprednisolone if acute rejection was 84 confirmed. Antithymocyte globulins were given to cases of steroid-resistant acute rejection. 85 Finally, patients with humoral acute rejection were treated by plasmapheresis and rituximab.

86 Recipients were given prophylaxis for human cytomegalovirus (HCMV). Seropositive recipients 87 who had received a transplant from a seropositive or a seronegative donor, and high-risk patients 88 (a seronegative recipient with a seropositive donor) were given valganciclovir prophylaxis (900 $89 \mathrm{mg} / \mathrm{d}$ if their creatinine clearance was $>60 \mathrm{ml} / \mathrm{min}$, and $450 \mathrm{mg} / \mathrm{d}$ if their creatinine clearance 90 was $<60 \mathrm{ml} / \mathrm{min}$ ) during the first 3 to 4 months post-transplantation.

\section{Virological monitoring}

92 All renal transplant recipients were tested prospectively for JCV excretion. Whole blood samples 93 were collected into potassium EDTA tubes from the time of transplantation to at least one year 94 post-transplant.

\section{Methods}

96 Measurement of blood JCV DNA

97 JC virus DNA was extracted automatically from whole blood and detected by quantitative real98 time PCR. The DNA was extracted from $200 \mu \mathrm{L}$ samples using a MagNA Pure ${ }^{\text {TM }}$ instrument 99 (Roche Diagnostics, Meylan, France) and the MagNA Pure LC DNA Isolation Kit I® according 
100 to the manufacturer's instructions. JCV DNA was detected using a Light Cycler ${ }^{\mathrm{TM}}$ system 101 (Roche).

102 The primers were located in the region coding for the agnoprotein: HMJC: 5'ATA CAg TgC 103 TTT gCC TgA ACC-3' and HMJC6: 5'-CAA CTg AgC AAT AgC ACT ACC-3'. The fluorogenic 104 probe was HSMSJC3: 6FAM-5'ACT ggA gCT CCg ggg gCT gTA 3’TAMRA. Real-time PCR was 105 carried out using Fast Start DNA Master hybridization probes (Roche Diagnostics, Meylan, 106 France). The use of specific primers and probes insures no cross reactivity with BKV. Extracted 107 DNA $(5 \mu \mathrm{L})$ was added to the PCR mixture containing $2 \mathrm{mmol} / \mathrm{L} \mathrm{MgCl}_{2}, 0.500 \mu \mathrm{mol} / \mathrm{L}$ of each 108 primer, and $0.100 \mu \mathrm{mol} / \mathrm{L}$ of probe. The PCR conditions were initial denaturation for one cycle 109 of $2 \mathrm{~min}$ at $50^{\circ} \mathrm{C}$ followed by $2 \mathrm{~min}$ at $95^{\circ} \mathrm{C}$, followed by 45 cycles of $20 \mathrm{~s}$ at $95^{\circ} \mathrm{C}$ and $60 \mathrm{~s}$ at 58

$110{ }^{\circ} \mathrm{C}$. Cooling was realised $30 \mathrm{~s}$ at $40{ }^{\circ} \mathrm{C}$. The reaction, data acquisition, and analyses were all 111 performed on a Light Cycler instrument. The PCR was checked for contamination using a 112 negative sample. JCV DNA load in whole blood is expressed as $\log _{10}$ genome copy number per 113 mL. Coupled with the MagNA Pure ${ }^{\mathrm{TM}}$ extraction, the detection limit was 500 copies genome per $114 \mathrm{~mL}$ (i.e. $2.7 \log _{10}$ copies $/ \mathrm{mL}$ ).

115 Patients were also tested for other opportunistic viral infections: cytomegalovirus (CMV), 116 Epstein-Barr virus (EBV), and BK virus (BKV) were quantified in whole blood and urine 117 samples (BKV).

118 HCMV DNA, EBV DNA, and BKV DNA were extracted automatically from whole blood with 119 the MagNA Pure ${ }^{\circledR}$ instrument. HCMV DNA was quantified on a Light Cycler 1.0 TM (Roche), as 120 described previously [Mengelle et al., 2003]. EBV DNA was quantified using a Light Cycler EBV 121 Quantification Kit ${ }^{\circledR}$ (Roche), according to the manufacturer's instructions [Gulley et al., 2006; 122 Hill et al., 2006; Kozic et al., 2006]. BKV DNA was quantified on a Light Cycler 2.0 ${ }^{\text {TM }}$ (Roche), 123 as described previously [Basse et al., 2007].

124 Serological markers 
125 Hepatitis B antigens were tested using the Ag HBs Architect (Abbott, Abbott Park, Illinois, 126 USA), and anti-HCV antibodies were tested using the anti-HCV Architect (Abbott). HBV DNA 127 and HCV RNA were quantified using the COBAS Ampliprep-COBAS Taqman96 $6^{\mathrm{TM}}$ (CAP128 CTM) system (Roche).

129 Anti-HCMV IgG and IgM were assayed using the Liaison CMV IgG and Liaison CMV IgM 130 assays according to the manufacturer's instructions (DiaSorin, Saluggie, Italy) Anti-VCA IgG and 131 anti-EBNA antibodies were tested using the Liaison VCA IgG and Liaison EBNA IgG. Anti132 VCA IgM antibodies were detected with the Liaison EBV IgM assays according to the 133 manufacturer's instructions (DiaSorin).

134 Statistical analyses

135 StatView 5.0 was used for all statistical analyses. The results are shown as means or medians. 
137 A total of 103 renal transplantations (68 men) were performed at the Toulouse University 138 Hospital between 1 January and 31 December, 2006. The mean age of the patients was 49.8 years 139 (range: $24-77$ years). Patients were enrolled for at least one year post-transplant. A total of 1487 140 whole blood samples were collected, and the median frequency of sampling was 12 (2-32) per 141 patient.

142 JCV was detected in 31 whole blood samples from seven of the 103 transplant patients (6.8\%), 143 two women and five men. Their mean age was 44 (23-70) years. Six patients had undergone a 144 first transplantation and one patient had undergone a second transplantation. The underlying 145 diagnoses were polycystic kidney disease $(n=2)$, thrombotic microangiopathy ( $n=1)$, focal 146 segmental glomerulosclerosis $(n=1)$, interstitial nephropathy $(n=1), \operatorname{IgA}$ nephropathy $(n=1)$, and 147 an undetermined cause.

148 Induction therapies were anti-CD25 monoclonal antibodies $(n=5)$ or antithymocyte globulins $149(n=2)$. Their post transplant immunosuppressive therapy included steroids with tacrolimus/MMF $150(n=2)$, or ciclosporin/MMF $(n=1)$, or belatacept/MMF $(n=4)$. Two patients were given 151 rituximab; one for a posttransplant focal segmental glomerulosclerosis relapse $\left(375 \mathrm{mg} / \mathrm{m}^{2}\right.$ 152 twice), and the other for an acute humoral rejection (375 mg/ $\mathrm{m}^{2} /$ week for 4 weeks).

153 No patient had hepatitis B surface antigens or anti-HCV antibodies. All patients were negative 154 for serum HBV DNA and HCV RNA. Five patients were anti-HCMV seropositive, and all were 155 anti-EBV positive at the time of transplantation.

156 The first positive JCV DNA sample was detected at a median time of 139 days post-transplant 157 (43-250). The median JC virus load of the first positive DNA blood sample was $3.4 \log _{10}$ 158 copies $/ \mathrm{mL}\left(1.9-5.7 \log _{10}\right.$ copies $\left./ \mathrm{mL}\right)$. JCV DNA was detected in only one blood sample taken 159 from three patients: at 43, 180, 225 days post-transplant and the virus loads were 4.5, 5.7 and 1.9 $160 \log _{10}$ copies $/ \mathrm{mL}$. The patient whose virus load was $5.7 \log _{10}$ copies $/ \mathrm{mL}$ was treated with 161 rituximab. 
162 JCV DNAemia was persistent in the other four (median 66 days, range 21-447). JCV DNA was

163 detected five times over 49 days in the one patient in this group who was treated with rituximab,

164 and the virus loads were very low $\left(3.1,2.5,2.5,0.6\right.$ and $2.5 \log _{10}$ copies $\left./ \mathrm{mL}\right)$.

165 All patients had other viral infection(s): BKV (3), EBV (2), CMV (1) and BK+EBV (1). EBV

166 infection occurred soon after transplantation: 27, 29, and 43 days, whereas the other infections

167 occurred later: BK at 51,115, 127, and 223 days post-transplant, and CMV at 194 days post-

168 transplant (in a HCMV seropositive patient). Fig. 1 summarizes the virological data for those

169 patients in whom JCV was detected.

170 The urine of three patients contained decoy cells. The blood samples of these patients also

171 contained BKV DNA: the first quantified BKV virus loads were 2.8, 4 and $4 \log _{10} \operatorname{copies} / \mathrm{mL}$, 172 and the urine BKV virus loads were $6.94,10.83$, and $10.89 \log _{10}$ copies/mL. First BKV DNA was 173 detected at a median time of 121 days post-transplant (51-223), and was prior to or at the same 174 time as JCV DNAemia. All three patients had a biopsy-confirmed polyomavirus-associated 175 nephropathy and had experienced acute rejection before BKV replication. The acute rejection 176 episodes had been treated with steroid injections alone (1), steroid injections and polyclonal 177 antibodies (1), and steroid injections, muromonab CD3, and rituximab (1). Pathological analysis 178 of a kidney biopsy taken from the fourth patient with BKV replication showed no features of 179 polyomavirus-associated nephropathy.

180 The median CD3 count was $733 / \mathrm{mm}^{3}(178-1717)$ and the median CD4 count was $470 / \mathrm{mm}^{3}$ 181 (78-1184) at the time of first JCV DNAemia, and the median creatinine was $1.39 \mathrm{mg} / \mathrm{dL}(1.12$ 182 2.93). The median microalbuminuria was $94 \mathrm{mg} / \mathrm{mL}$ (25-244), the median hematuria was 9 183 cells $/ \mathrm{mm}^{3}(0-28)$, and the median leukocyturia was 3 cells $/ \mathrm{mm}^{3}(0-80)$. 


\section{Discussion}

185 Although BKV is known to be associated with polyomavirus-associated nephropathy in renal 186 transplant recipients, little is known on the consequence of a JCV infection. In this study, the 187 incidence of JCV infection was determined in a long-term follow-up of renal transplant patients. 188 The incidence was similar to that found by Razonable et al., [2005], who detected JCV DNA in 189 the blood of $7.6 \%$ of renal transplant patients during the first year post-transplant. The incidence 190 of JCV is similar to that of BKV DNAemia that was reported previously for the renal transplant 191 patients at Toulouse University Hospital [Basse et al., 2007]. Some authors have not detected JCV 192 DNA in the blood of renal transplant and liver transplant patients [Randhawa et al., 2005], 193 whereas others have reported rare, transient and low viremia [Drachenberg et al., 2007]. In this 194 study, whole blood samples rather than plasma or leukocyte specimens were used to quantify 195 JCV DNA. Whole blood samples might increase the sensitivity of JCV detection, as has been 196 described for other viruses [Basse et al., 2007; Drachenberg et al., 2007; Fafi-Kremer et al., 2004; 197 Garrigue et al., 2006; Gouarin et al., 2004], and could explain why current results differ from 198 those of other studies.

199 Urine samples were not tested regularly for JCV. BKV viruria is rare in immunocompetent 200 patient and is clearly associated with disruptions of cellular immunity, as demonstrated in bone 201 marrow transplant recipients [Doerries, 2006] and in patients infected with HIV [Hirsch and 202 Steiger, 2003]. In contrast, JCV is found commonly in the urine of immunocompetent patients: 203 JCV remains latent in the renal parenchyma after primary infection, and may be excreted in non204 immunosuppressed individuals. It is found frequently in the urine of elderly persons in particular 205 [Chang et al., 2002; Kitamura et al., 1997]. This was why urine samples were not tested regularly; 206 positive results would have had to be been interpreted cautiously.

207 The association of JCV and polyomavirus-associated nephropathy has been documented in 208 isolated cases [Kazory et al., 2003; Randhawa et al., 2005; Wen et al., 2004]. Only the blood of 209 patients with polyomavirus-associated nephropathy contained JCV DNA, even at low 
210 concentrations [Drachenberg et al., 2007]. Such an association was not observed in the current

211 study, none of the patients whose blood contained JCV DNA suffered from any polyomavirus-

212 associated nephropathy whatever the virus load. Only three patients had decoy cells at the time of

213 JCV excretion: they were all infected with BKV with a very high virus loads in whole blood and

214 urine, indicating BKV-associated nephropathy, as shown by others [Randhawa et al., 2005;

215 Viscount et al., 2007].

216 None of the patients had any neurological symptoms and no cases of multifocal leuko217 encephalopathy were diagnosed during follow-up. Several cases of multifocal 218 leukoencephalopathy have been reported recently in haematological [Pelosini et al., 2008] and 219 bone marrow transplant patients [Goldberg et al., 2002] treated with rituximab. Kamar et al. 220 [2009] reported that the incidence of JCV DNAemia in 73 rituximab-treated solid-organ 221 transplant patients was 5.5\%, but no neurological disorder was found during long-term follow-

222 up. In the present study, only two of the seven JCV-infected patients were treated with rituximab, 223 these results are very similar to those of the previous study. Overall, the JC virus loads were not 224 correlated with any clinical manifestations.

225 Frequent mixed infections with other opportunistic virus were detected in whole blood sample. 226 In particular, mixed BKV and JCV infections were observed in whole blood samples of four 227 patients. Three patients had biopsy-confirmed BKV nephropathy, but no significant relationship 228 could be established between mixed infection and clinical manifestations since these 229 opportunistic infections were detected prior to or at the same time as JCV. This high incidence of 230 mixed infections, which reflects heavy immunosuppression, has not been described previously 231 [Drachenberg et al., 2007; Randhawa et al., 2005; Watcharananan et al.], although 232 immunosuppressive therapy was as potent as in this study: i.e., kidney transplant patients induced 233 with anti-CD52 antibodies (alemtuzumab) followed by tacrolimus monotherapy. 
235 In conclusion, the present monocentric study shows that JCV infections are relatively uncommon

236 in renal transplant recipients. They were not associated with acute renal rejection, or with the

237 presence of decoy cells in the JCV DNAemia positive patients, suggesting that the course of JCV

238 infection is lower and less aggressive than of BKV. No association between JCV infection and

239 neurological manifestations was also detected. Overall, these results are comparable to those of

240 Razonable et al., [2005], who found episodes of subclinical JCV DNA in the blood of solid-organ

241 transplant patients.

242 However, JCV infection should be surveyed regularly in transplant recipients as the presence of

243 JCV DNA in the blood may differentiate between JCV and BKV infections. Therefore, detection

244 of JCV indicates over-immunosuppressed patients who may benefit from reduction of 245 immunosuppressive treatment. 


\section{References}

247 Allander T, Andreasson K, Gupta S, Bjerkner A, Bogdanovic G, Persson MA, Dalianis T,

248 Ramqvist T, Andersson B. 2007. Identification of a third human polyomavirus. J Virol 249 81(8):4130-4136.

250 Basse G, Mengelle C, Kamar N, Guitard J, Ribes D, Esposito L, Rostaing L. 2007. Prospective 251 evaluation of BK virus DNAemia in renal transplant patients and their transplant 252 outcome. Transplant Proc 39(1):84-87.

253 Chang H, Wang M, Tsai RT, Lin HS, Huan JS, Wang WC, Chang D. 2002. High incidence of JC 254 viruria in JC-seropositive older individuals. J Neurovirol 8(5):447-451.

255 Doerries K. 2006. Human polyomavirus JC and BK persistent infection. Adv Exp Med Biol $256 \quad 577: 102-116$

257 Drachenberg CB, Hirsch HH, Papadimitriou JC, Gosert R, Wali RK, Munivenkatappa R, 258 259 Nogueira J, Cangro CB, Haririan A, Mendley S, Ramos E. 2007. Polyomavirus BK versus JC replication and nephropathy in renal transplant recipients: a prospective evaluation. Transplantation 84(3):323-330.

Fafi-Kremer S, Brengel-Pesce K, Bargues G, Bourgeat MJ, Genoulaz O, Seigneurin JM, Morand P. 2004. Assessment of automated DNA extraction coupled with real-time PCR for measuring Epstein-Barr virus load in whole blood, peripheral mononuclear cells and plasma. J Clin Virol 30(2):157-164.

Garrigue I, Boucher S, Couzi L, Caumont A, Dromer C, Neau-Cransac M, Tabrizi R, Schrive MH, Fleury H, Lafon ME. 2006. Whole blood real-time quantitative PCR for cytomegalovirus infection follow-up in transplant recipients. J Clin Virol 36(1):72-75.

268 Gaynor AM, Nissen MD, Whiley DM, Mackay IM, Lambert SB, Wu G, Brennan DC, Storch 269 GA, Sloots TP, Wang D. 2007. Identification of a novel polyomavirus from patients with 270 acute respiratory tract infections. PLoS Pathog 3(5):e64. 
271 Goldberg SL, Pecora AL, Alter RS, Kroll MS, Rowley SD, Waintraub SE, Imrit K, Preti RA. 2002. Unusual viral infections (progressive multifocal leukoencephalopathy and cytomegalovirus disease) after high-dose chemotherapy with autologous blood stem cell rescue and peritransplantation rituximab. Blood 99(4):1486-1488.

Gouarin S, Vabret A, Gault E, Petitjean J, Regeasse A, Hurault de Ligny B, Freymuth F. 2004. Quantitative analysis of HCMV DNA load in whole blood of renal transplant patients using real-time PCR assay. J Clin Virol 29(3):194-201.

Gulley ML, Fan H, Elmore SH. 2006. Validation of Roche LightCycler Epstein-Barr virus quantification reagents in a clinical laboratory setting. J Mol Diagn 8(5):589-597.

Hill CE, Harris SB, Culler EE, Zimring JC, Nolte FS, Caliendo AM. 2006. Performance characteristics of two real-time PCR assays for the quantification of Epstein-Barr virus DNA. Am J Clin Pathol 125(5):665-671.

Hirsch HH, Steiger J. 2003. Polyomavirus BK. Lancet Infect Dis 3(10):611-623.

Hou J, Major EO. 2000. Progressive multifocal leukoencephalopathy: JC virus induced demyelination in the immune compromised host. J Neurovirol 6 Suppl 2:S98-S100.

Kamar N, Mengelle C, Rostaing L. 2008. Incidence of JC-virus replication after rituximab therapy in solid-organ transplant patients. Am J Transplant 9 (1):244-245.

Kazory A, Ducloux D, Chalopin JM, Angonin R, Fontaniere B, Moret H. 2003. The first case of JC virus allograft nephropathy. Transplantation 76(11):1653-1655.

Kitamura T, Sugimoto C, Kato A, Ebihara H, Suzuki M, Taguchi F, Kawabe K, Yogo Y. 1997. Persistent JC virus (JCV) infection is demonstrated by continuous shedding of the same JCV strains. J Clin Microbiol 35(5):1255-1257.

Knowles WA, Pipkin P, Andrews N, Vyse A, Minor P, Brown DW, Miller E. 2003. Populationbased study of antibody to the human polyomaviruses BKV and JCV and the simian polyomavirus SV40. J Med Virol 71(1):115-123. 
296 Kozic S, Vince A, Bes JI, Rode OD, Lepej SZ, Poljak M, Bozic M, Kessler HH. 2006. Evaluation of a commercial real-time PCR assay for quantitation of Epstein-Barr virus DNA in different groups of patients. J Virol Methods 135(2):263-268.

Lafon ME, Dutronc H, Dubois V, Pellegrin I, Barbeau P, Ragnaud JM, Pellegrin JL, Fleury HJ. 1998. JC virus remains latent in peripheral blood B lymphocytes but replicates actively in urine from AIDS patients. J Infect Dis 177(6):1502-1505.

Mengelle C, Sandres-Saune K, Pasquier C, Rostaing L, Mansuy JM, Marty M, Da Silva I, Attal M, Massip P, Izopet J. 2003. Automated extraction and quantification of human cytomegalovirus DNA in whole blood by real-time PCR assay. J Clin Microbiol 41(8):3840-3845.

Monaco MC, Atwood WJ, Gravell M, Tornatore CS, Major EO. 1996. JC virus infection of hematopoietic progenitor cells, primary B lymphocytes, and tonsillar stromal cells: implications for viral latency. J Virol 70(10):7004-7012.

Pagani E, Delbue S, Mancuso R, Borghi E, Tarantini L, Ferrante P. 2003. Molecular analysis of JC virus genotypes circulating among the Italian healthy population. J Neurovirol $9(5): 559-566$.

Pelosini M, Focosi D, Rita F, Galimberti S, Caracciolo F, Benedetti E, Papineschi F, Petrini M. 2008. Progressive multifocal leukoencephalopathy: report of three cases in HIV-negative hematological patients and review of literature. Ann Hematol 87(5):405-412.

Randhawa P, Uhrmacher J, Pasculle W, Vats A, Shapiro R, Eghtsead B, Weck K. 2005. A comparative study of BK and JC virus infections in organ transplant recipients. J Med Virol 77(2):238-243.

Razonable RR, Brown RA, Humar A, Covington E, Alecock E, Paya CV. 2005. A longitudinal molecular surveillance study of human polyomavirus viremia in heart, kidney, liver, and pancreas transplant patients. J Infect Dis 192(8):1349-1354. 
321 Rossi A, Delbue S, Mazziotti R, Valli M, Borghi E, Mancuso R, Calvo MG, Ferrante P. 2007.

Presence, quantitation and characterization of JC virus in the urine of Italian

324 Viscount HB, Eid AJ, Espy MJ, Griffin MD, Thomsen KM, Harmsen WS, Razonable RR, Smith

327 Watcharananan SP, Kiertiburanakul S, Piyatuctsanawong W, Anurathapan U, Sungkanuparph S,

328 Pakakasama S, Chantratita W, Hongeng S. Cytomegalovirus, adenovirus, and polyomavirus co-infection among pediatric recipients of allogeneic stem cell transplantation: characteristics and outcome. Pediatric transplantation 14(5):675-681.

Wen MC, Wang CL, Wang M, Cheng CH, Wu MJ, Chen CH, Shu KH, Chang D. 2004.

Association of JC virus with tubulointerstitial nephritis in a renal allograft recipient. J Med Virol 72(4):675-678. 